\title{
Transitional care interventions from acute care to long-term care facilities: a systematic review
}

\author{
Melanie Le Berre ${ }^{1}$, Anshuman Saksena ${ }^{2}$, Isabelle Vedel $^{2}$, and Machelle Wilchesky ${ }^{2}$ \\ ${ }^{1}$ Lady Davis Institute for Medical Research \\ ${ }^{2}$ McGill University
}

May 5, 2020

\begin{abstract}
Objectives: Older adults living in long-term care facilities (LTCFs) are particularly at risk during transitions in care, most notably from acute care back to their LCTF. Issues surrounding miscommunication of information or medications are often mentioned as important challenges. Transitional care interventions (TCi) have emerged as solutions to improve outcomes. The objective of this review was therefore to determine the effects of TCi on several indicators of quality of care, clinical outcomes, healthcare services use and satisfaction among older patients discharged from acute care to LTCFs. Methods: Medline, CINAHL, EMBASE, Cochrane Central and Social Work Abstracts were searched. Study selection (title/abstract, full-text), data extraction and assessment of study quality were conducted by two independent reviewers. A narrative synthesis of the data was performed. Results: From the 5,506 references identified, 11 were included. Eight studies reported on quality of care: six on medication problems, and two on advance directives. Four studies reported on clinical outcomes: three on mortality, two on mobility/function and one on confusion/behavioral symptoms. Seven studies reported on healthcare services use: six on hospital readmissions/ED visits, and five on hospital days. Three studies reported on satisfaction with TCi. While satisfaction levels were high with $\mathrm{TCi}$, other outcomes were inconclusive. Medications problems appeared to be the outcome most likely to benefit from TCi. Discussion: TCi targeting the acute to long-term care transition have obtained inconclusive results so far. More studies investigating the outcomes of quality of care, clinical outcomes, healthcare services use are needed.
\end{abstract}

\section{KEYWORDS:}

Transition models; Health outcomes; Health services use; Nursing Homes

\section{Introduction}

Healthcare systems are currently facing an increasing number of vulnerable older patients who often require complex services and care. Older adults living in long-term care facilities (LTCFs) represent one of the most vulnerable groups in the geriatric population. ${ }^{1}$ Often described as the "oldest old", more than $45 \%$ of them are aged over 85 years old in the United States. ${ }^{1,2}$ This number is expected to grow further in the upcoming years to reach 19 million by 2050 only in the United States. ${ }^{3}$ They are expected to represent over $4 \%$ of the total American population ${ }^{3}$ and almost $6 \%$ of the Canadian population in thirty years. ${ }^{4}$ Older adults living in LTCFs also typically present multiple chronic diseases and require high levels of assistance for basic functional tasks. ${ }^{2}$ Conditions associated with elevated care demands or with a potentially challenging management ${ }^{5,6}$ were found to be highly prevalent in this setting: up to $52 \%$ of LTCFs residents live with dementia or other related neurocognitive disorder, up to $49 \%$ with vascular diseases, including $21 \%$ with congestive heart failure, and up to $37 \%$ with depression. ${ }^{1}$ With this profile, older adults living in LTCFs are 
also particularly at risk of poor outcomes during transitions in care settings, such as from acute to long-term care (LTC). ${ }^{7}$

To explain this situation, issues pertaining to gaps in information about medical information, treatment plans, or modifications to medications prescribed are often raised..$^{7-9}$ King et al (2013) reported that "poor quality discharge communication" is the main barrier to a safe and well executed transition miscommunication being associated with increased readmissions and medication errors, delays in providing care, and decreased satisfaction of healthcare professionals, caregivers and patients. ${ }^{7,10}$ Acute care stays constitute dramatic interruptions in the relationships and patterns of care previously put in place between the LTCFs staff and the residents and their family. ${ }^{11}$ Hospital charts or discharge forms about the procedures or investigations performed and the modifications made to medications regimen may also not be adequately transmitted to LTCFs during the transfer. ${ }^{12}$ As all acute care stays are not avoidable, ${ }^{13-15}$ the transition from acute to LTC represents a key issue for the care of the most vulnerable of older adults: the LTCFs residents. Transitional care interventions (TCi), such as timely medication reconciliation, ${ }^{16}$ formal post-discharge follow-up ${ }^{17-19}$ or early transmission of a tailored communication forms, ${ }^{20,21}$ have emerged as an answer to poorly executed transitions and their consequences. They commonly aim to enhance the communication and the collaboration between the sites of care ${ }^{7}$ which are both particularly relevant to the acute care to LTC transition.

Some TCi studies in older populations with complex care needs have reported promising results on both clinical and health service use outcomes. ${ }^{22}$ Existing reviews on TCi, even when targeting the older population with complex care needs, however, have focused mainly on those conducted in community-dwelling patients. ${ }^{22}$ Furthermore, TCi reviews that did involve the LTCF settings have evaluated transitions from long-term to acute care settings, rather than from the acute care setting to LTC. ${ }^{9}$ These reviews also did not distinguish between Emergency Department (ED) visits and inpatient admission, as both were labelled in the "hospital" category. The effects of TCi on the transitions from acute care to a LTCF facility remains poorly studied. Therefore, we conducted a systematic review to comprehensively explore the effects of TCis for older adults transferred from the acute to LTC setting.

\section{Methods}

This systematic review followed the standard guidelines of Preferred Reporting Items for Systematic Reviews and Meta-Analyses (PRISMA). The review protocol was registered with the PROSPERO international prospective register of systematic reviews (registration number: CRD42016049061)

\section{Eligibility Criteria}

Study design : all quantitative studies (randomized controlled trials, observational or quasi-experimental studies, etc...).

Population: Older adults (aged 65 and over) from all countries, being discharged from acute care hospital in-patient stays to a LTCF. For the purpose of the study, LTC will be defined as health services provided for people with complex health needs/moderate to extensive functional deficits or chronic conditions, who are unable to remain at home or in a supportive living environment, and involving nursing care and personal care. ${ }^{23}$ Acute care hospital in-patient stays could be for any health condition (i.e. frailty, geriatric syndrome, hip fracture, stroke, Alzheimer/dementia, multimorbidity, chronic disease exacerbation, oncology, infection...), planned or unplanned.

Interventions : Any TCi, defined as "a set of actions designed to ensure the coordination and continuity of healthcare as patients transfer between different locations or different levels of care within the same location". ${ }^{24}$ In this study, TCis were included if they targeted an acute care hospital in-patient discharge back to a LTCF. TCis could include care/discharge planning in conjunction with the patients/caregivers/nursing home personnel, systematic medication reconciliation by a pharmacist, telecare/telemedicine/telemonitoring, 
formal discharge summary, structured follow-up and coordination among the different healthcare professionals.

Outcomes : Any quality of care, patient-related and healthcare services use reported outcomes.

A fully detailed list of inclusion/exclusion criteria is available in Supplementary Table 1.

\section{Data Sources and Searches}

Systematic searches were performed in Medline, CINHAL, EMBASE, Cochrane Central and Social Work Abstracts combining the concepts of LTC, hospital, older population and transitional care. We used MeSH terms and related and free key words (see Supplementary Table 2 for a more detailed search strategy).

Reference lists of included studies were screened manually and companion papers were searched. Articles published between January $1^{\text {st }}, 1995$ (first TCis) and October, 2016 were considered for inclusion.

\section{Study Selection}

Based on inclusion criteria, two reviewers (MLB, AS) independently examined and selected the titles and abstracts obtained from the database searches. Full texts of the selected references were then retrieved and independently examined and selected by the same reviewers. At each step, any disagreement was resolved by consensus and discussion with a third reviewer (MW or IV).

\section{Data Extraction and Quality Assessment}

Data on study characteristics (authors, publication date, title, journal, study design), settings and participants (country, mean age, proportion of female, sample size, percentage going to a LTCF, reason of hospitalization, description of the intervention, healthcare professionals involved in the intervention, any coordination measures with the LTCF) were extracted from each study by two reviewers working independently (MLB, AS) and reconciled. Outcomes on quality of care (i.e. medication errors), patient-related (i.e. mortality, health-related outcomes) and healthcare services use (readmission, ED visits and total readmission days) were similarly extracted from the studies for all reported time points.

Study quality was assessed independently by two reviewers (MLB, AS) using the latest version Mixed Methods Appraisal Tool (MMAT), updated in 2018. ${ }^{25}$

\section{Data Synthesis and Analysis}

The wide variety of the reported outcomes and the discrepancy of the various cutoffs used (i.e. "Patients with at least 1 medication error", "Patients with at least 3 medication errors" and "Patients with at least 5 medication errors") precluded any meta-analysis pooling. Thus, we conducted a narrative synthesis ${ }^{26}$ by organizing the included studies into homogeneous groups according to the outcome of interest.

We thus reported the results, regrouped by the main key study outcomes identified: "Quality of care" (medication problems, and advance directives), "Clinical outcomes" (mortality, mobility and function and confusion/behavioral symptoms), "Services use" (hospital readmissions and ED visits and hospital days) and "Satisfaction" with TCi (from either healthcare professionals or patients/caregivers). We then looked for patterns within and across groups and compared similarities and differences.

A sensitivity analysis was performed by exploring the results with and without the studies with at least one MMAT item with a negative response in each identified study outcome. ${ }^{25}$ 


\section{Results}

\section{Search Results}

A total of 5,506 references were initially identified from the databases searches. Of these, 5,375 were not eligible based on title/abstract screening and 121 based on full text reading. Eleven studies were finally included in the review: two randomized controlled trials (RCTs) and nine nonrandomized studies (Figure $1)$.

\section{Characteristics of Included Studies}

All the articles were published in English. The characteristics of the included studies are summarized in Table 1.

\section{Quality of care}

Eight different studies reported on quality of care indicators (Table 2): six reported on medication problems ${ }^{12,16,18,20,27,28}$ and two on advance directives. ${ }^{21,29}$

Overall, the effects of TCi on medication problems were inconclusive: Four studies reported favorable TCi results ${ }^{12,16,27,28}$ with significantly fewer medication errors per patient, ${ }^{27,28}$ significantly lower odds of having discrepancy-related adverse drug events ${ }^{16}$ and significantly fewer patients with one or more missed or delayed doses. ${ }^{12}$ One study reported no significant differences between the intervention and control groups. ${ }^{18}$ One study also reported better results in the control group. ${ }^{20}$

Among studies reporting TCi involving advance directives, two reported positive effects on the quality of care. One study found that the satisfaction with Advance Care Planning was significantly higher in patients and caregivers enrolled in a TCi ${ }^{29}$ Another study reported significantly less discrepancy in advance directives documentation and Do-Not-Resuscitate orders between the acute and LTC settings. ${ }^{21}$

\section{Clinical outcomes}

Four different studies reported on clinical outcomes (Table 3): three on mortality, ${ }^{16,17,29}$ two on mobility, function and pain ${ }^{17,18}$ and one on confusion/behavioral symptoms. ${ }^{18}$

No studies reported a beneficial effect of TCi on mortality. One study only reported composite data, combining deaths and readmissions, with no significant differences between the post-intervention and preintervention groups. ${ }^{16}$ Another study reported very similar results for both the intervention and usual care groups. ${ }^{29}$ Lastly, in a study that compared two interventions and did not include a control group, the authors reported reduced mortality with a tailored TCi as compared with standardized TCi. ${ }^{17}$ In tailored $\mathrm{TC}$, the number of follow-up visits and the healthcare professional performing them (physician, nurse or physiotherapist) was adapted according to the case and needs, whereas a strict protocol was followed in standardized TCi.

In terms of mobility, function and pain outcomes, reported results have been inconclusive. One study which reported on multiple outcomes found significantly fewer cases of worsening pain with TCi, compared with the control group, and fewer cases of decline in mobility with TCi but this difference was not statistically significant. This same study also reported a slightly higher number of falls in the TCi group, but this was also not statistically significant. ${ }^{18}$ One study found very similar effect between a tailored intervention and a standardized intervention when looking at functional autonomy differences measured using the "modified Barthel index" by Gregersen et al (2011) before and after the intervention period. 
Finally, one study reported on confusion and behavioral symptoms. The authors reported fewer cases of confusion and fewer cases of worsening behavior with TCi but these differences were not statistically significant. ${ }^{18}$

\section{Satisfaction}

Three different studies reported on satisfaction with $\mathrm{TCi}$ by either healthcare professionals or patients/caregivers (Table 3). ${ }^{12,29,30}$ In all three studies, patients, caregiver and healthcare professionals interviewed all reported high levels of satisfaction with TCi. ${ }^{12,29,30}$

\section{Healthcare services use}

Seven different studies reported on healthcare services use (Table 4): six evaluated hospital readmissions and ED visit outcomes, ${ }^{16-19,21,29}$ and five assessed changes in the number of hospital days. ${ }^{16,17,21,28,29}$ The results pertaining to hospital readmissions and ED visits are inconclusive. Two studies out of six showed a beneficial effect of TCi, with a significantly lower percentage of patients readmitted, ${ }^{19}$ and significantly reduced hospital usage (combining readmissions and $\mathrm{ED}$ visits) associated with $\mathrm{TCi} .{ }^{18} \mathrm{~A}$ third study also reported fewer patients readmitted after TCi implementation, but this difference was not statistically significant. ${ }^{21}$ Two studies found no significant differences between TCi and usual care on hospital readmissions or on the combination of deaths and hospital readmissions. ${ }^{16,29}$ Lastly, the study that compared two interventions which did not include a control group reported reduced readmissions rate with the tailored as compared with the standardized TCi. ${ }^{17}$

Results have also been inconclusive as it pertains to studies measuring changes in length of stay. In one study, the authors reported a significantly shorter index stay with TCi. ${ }^{16}$ Two other studies found very similar numbers, both for index stay hospital days ${ }^{28,29}$ and hospital days during readmissions. ${ }^{29}$ An additional study found a longer index stay with the implementation of TCi but the difference was not statistically significant. ${ }^{21}$ Lastly, one study found no differences in index length of stay between the participants enrolled in the tailored TCi or standardized TCi. ${ }^{17}$

\section{Study Quality Appraisal}

The quality of each of the eleven included studies was assessed using the 2018 updated MMAT (Supplementary Table 3). ${ }^{25}$ All RCTs reported appropriate randomization and all nonrandomized studies reported including participants representative of their identified target population. Yet, the confounders were reported as adequately accounted for in only $56 \%(5 / 9)$ of the nonrandomized studies and the intervention was explicitly reported to have been administered as intended in only $33 \%(3 / 9)$ of the nonrandomized studies. Four studies $(36 \%)$ had at least one MMAT item with a negative response and seven (64\%) had at least one MMAT item with the mention "can't tell". Additionally, even among studies adequately reporting all the outcomes mentioned in their methods section, p-values were not commonly reported.

\section{Sensitivity analyses}

Out of 11 studies, 4 had at least one MMAT item with a negative response (Supplementary Table 3). ${ }^{18,19,21,29}$ The general conclusions for each outcome did not change when removing these four studies from the data synthesis. After removing these four studies, only five different studies reported on quality of care: five on medication problems ${ }^{12,16,20,27,28}$ and none on advance directives. Four still showed favorable results ${ }^{12,16,27,28}$ with TCi and one showed better results in the control group. ${ }^{20}$

Additionally, after removing these four studies, only two different studies reported on clinical outcomes: two on mortality, ${ }^{16,17}$ one on mobility, function and pain $^{17}$ and none on confusion/behavioral symptoms. There was still no beneficial effect of TCi on mortality and inconclusive results on mobility, function and pain. 
For healthcare services use, after removing these four studies, only three different studies still reported data: two on hospital readmissions and ED visits ${ }^{16,17}$ and three on hospital days. ${ }^{16,17,28}$ The results were still inconclusive for both hospital readmissions and ED visits and hospital days.

Finally, after removing these four studies, only two different studies reported on satisfaction. ${ }^{12,30}$ Both caregivers and physicians still showed high levels of satisfaction with TCi.

\section{Discussion}

This systematic review presents the effects of TCi on quality of care, clinical outcomes and healthcare services use outcomes among older adults transferring from the acute care to the LTCF setting. Medications problems (quality of care), hospital readmission and ED visits (healthcare services use) and hospital days (healthcare services use) were the most documented outcomes, with data from six, six and five studies respectively. The reported results were however inconsistent. Medications problems as an outcome seemed nevertheless to hold the most promising results, with four individual studies out of six reporting significantly favorable results with TCi. ${ }^{12,16,27,28}$ Additionally, high levels of satisfaction were achieved with TCi.

Our results show that medications problem outcomes are the most likely to be reported as benefiting from TCi. Indeed, medications problems could represent an important target to improve care during transitions from acute care to LTC. More studies investigating more closely this outcome would be needed to confirm these results. Yet, previous studies reported that adverse drug events attributable to medication changes occur in $20 \%$ of patients going from acute care to LTC, ${ }^{31}$ with medication errors occurring during these transitions as being most harmful to patients. ${ }^{32}$ In the context where information gaps are reported in over $85 \%$ of transfers between ED and LTC, ${ }^{33}$ this suggests that medications problems might be addressed by improving communication. Indeed, all four interventions where the situation improved significantly involved a specific discharge summary or communication form sent to the LTC setting before or at the time of patient transfer. These interventions further emphasized the importance of medication clarification, either through a formal medication reconciliation ${ }^{16,27,28}$ or via completion and transmission of a discharge prescriptions form. ${ }^{12}$ It is worth noting that these four studies also involved a pharmacist as key healthcare professional in carrying out the intervention. ${ }^{12,16,27,28}$ Of the studies where no effect was reported, one used fax as a communication strategy, ${ }^{18}$ and important concerns have been raised about the use of this technology. ${ }^{34}$ The other was a quality improvement pilot study that was possibly insufficiently powered to detect a significant change (10 patients in each group). The authors of this pilot study raised the issue of a possible unsuccessful implementation of the intervention and important group differences, notably in their health status and medication orders patterns. ${ }^{20}$

Our results further suggested that increased communication between hospitals and LTC, including medication reconciliation or specific transfer forms, was not enough to decrease healthcare services use (hospital readmission and $\mathrm{ED}$ visits, hospital days). In this regard, the timing of the communication might be a key element to consider. Indeed, the recommendations to improve transitional care were not only to increase the communication per se but rather to "facilitate the timely transfer of essential information across settings". ${ }^{7}$ In the case of the acute care to LTCF transition, this "timely" criterion could translate into the early transmission of the medications list before discharge, to ensure that the medications are ready to be administered upon patient's arrival and to avoid delayed doses. ${ }^{12}$ This would further allow LTCF's physicians time to review the patients' chart and status at an appropriate time rather than through an urgent visit or via a locum tenens. ${ }^{12}$

Among the frail population residing in LTC, transfers to the acute care setting are challenging and stressful life events. ${ }^{8}$ This is especially true for cognitively impaired patients, ${ }^{35}$ who constitute between $45-84 \%$ of the LTC population. ${ }^{1,36}$ To address this issue, upstream interventions aiming to reduce potentially avoidable transfers to acute care are warranted. ${ }^{8,37}$ Admissions to acute care, however, cannot always be prevented, and may continue to represent a part of the care trajectory for some patients, ${ }^{13,14}$ with a 2000 study sug- 
gesting that $60 \%$ of hospital admissions are necessary and recommended. ${ }^{15}$ As part of quality improvement initiatives, several LTCFs worldwide have implemented interventions to reduce potentially avoidable hospital admissions, ${ }^{38}$ and TCi between these two care settings remain a highly relevant research area. The characteristics and particular components of impactful and efficient TCi in this specific context are still to be determined.

Our study also highlights the high levels of satisfaction reported by patients, caregiver and physicians with TCi. Enhanced continuity of care associated with TCi is particularly valued by older vulnerable patients, and can foster a strong foundation for a better communication with patients, and caregivers. It can also result in a greater sense of security and trust in the healthcare system overall. ${ }^{39} \mathrm{In}$ our review, the three studies reporting high satisfaction involved either phone calls or in-person support and sharing of information. ${ }^{12,29,30}$ Additionally, gaps in information exchange during transitions resulting in missing data from the medical charts of transferred patients can lead to frustration, increased work-stress and feelings of inadequacy and guilt among healthcare professionals working in LTC. ${ }^{10} \mathrm{TCi}$ focusing on improving inter-facility communication are therefore also warranted.

This review has many strengths, starting with its systematic design and exhaustive literature search. Another strength is the fact that we focused specifically at TCi for older patients transitioning from acute care to LTC setting. Our review's principle limitation stems from heterogeneity in both the outcomes reported from each study and in the various tools used as interventions. This prevented us from conducting a meta-analysis and pooling results, but it did allow for a narrative synthesis that provides a rich and in-depth overview of the available relevant literature. Our study also suffered from a paucity of eligible articles in our sample. We identified only 11 studies, among which only 2 were randomized trials, whereas reviews reporting on TCi in other settings are usually much larger, with some reporting on up to 92 studies. $^{22}$ Our small sample also limited our pooling possibilities and further highlights the need for more TCi studies targeting transfers to the LTC setting. Lastly, our sample quality appraisal MMAT scoring revealed reporting issues among several studies in our sample, with 4 studies receiving at least one negative MMAT item response, and a total of 7 where it was unclear whether or not an MMAT criterion was satisfied. P-values were also not routinely reported.

Future studies should aim to report standardized outcomes and their related p-values, using validated and relevant indicators to facilitate the pooling of data. Authors should also strengthen their efforts towards higher quality of reporting.

\section{Conclusions and implications}

TCi targeting older adults being transferred from acute care to the LTC setting aim to improve the transitions for the most vulnerable among the geriatric population. ${ }^{1}$ Our review, however, was able to identify only a limited number of relevant studies, in spite of conducting an exhaustive search, and found that the literature is fraught with inconsistent results. In the identified interventions, a focus on medication reconciliation and timely intra-institutional communication appear to be important components that improve the acute care to LTCF transitions in this population. Future research should include well-designed large-scale TCi using standardized and validated outcome measures in order to improve our understanding of the effects of TCi on LTC patients being discharged from acute care.

\section{References}

1. Moore KL, Boscardin WJ, Steinman MA, Schwartz JB. Age and Sex Variation in Prevalence of Chronic Medical Conditions in Older Residents of US. Nursing Homes. Journal of the American Geriatrics Society.2012;60(4):756-764. 2. Park-Lee E, Sengupta M, Bercovitz A, Caffrey C. Oldest old long-term care recipients: findings from the national center for health statistics' longterm care surveys. Research on Aging.2013;35(3):296-321. 3. Vincent G, K, Velkoff VA. THE 
NEXT FOUR DECADES. The Older Population in the United States: 2010 to 2050. Population Estimates and Projections 2010; https://www.census.gov/prod/2010pubs/p25-1138.pdf. 4. Martel L, Hagey J. A portrait of the population aged 85 and older in 2016 in Canada. Census in Brief 2017; https://www12.statcan.gc.ca/census-recensement/2016/as-sa/98-200-x/2016004/98200-x2016004-eng.cfm. 5. Bynum JP, Rabins PV, Weller W, Niefeld M, Anderson GF, Wu AW. The relationship between a dementia diagnosis, chronic illness, medicare expenditures, and hospital use. Journal of the American Geriatrics Society. 2004;52(2):187-194. 6. Heckman GA, Boscart VM, D'Elia T, et al. Managing heart failure in long-term care: Recommendations from an interprofessional stakeholder consultation. Canadian Journal on Aging/La Revue canadienne du vieillissement. 2016;35(4):447-464. 7. Coleman EA. Falling through the cracks: challenges and opportunities for improving transitional care for persons with continuous complex care needs. Journal of the American Geriatrics Society.2003;51(4):549-555. 8. Konetzka RT, Spector W, Limcangco MR. Reducing hospitalizations from long-term care settings. Medical Care Research and Review.2008;65(1):40-66. 9. LaMantia MA, Scheunemann LP, Viera AJ, Busby-Whitehead J, Hanson LC. Interventions to improve transitional care between nursing homes and hospitals: a systematic review. Journal of the American Geriatrics Society. 2010;58(4):777-782. 10. King BJ, Gilmore-Bykovskyi AL, Roiland RA, Polnaszek BE, Bowers BJ, Kind AJ. The consequences of poor communication during transitions from hospital to skilled nursing facility: a qualitative study. Journal of the American Geriatrics Society. 2013;61(7):1095-1102. 11. Toles M, Young H, Ouslander J. Improving care transitions in nursing homes. Generations. 2012;36(4):78-85. 12. Elliott RA, Tran T, Taylor SE, et al. Impact of a pharmacist-prepared interim residential care medication administration chart on gaps in continuity of medication management after discharge from hospital to residential care: a prospective pre-and post-intervention study (MedGap Study). BMJ open.2012;2(3):e000918. 13. Numico G, Cristofano A, Mozzicafreddo A, et al. Hospital admission of cancer patients: avoidable practice or necessary care? PloS one. 2015;10(3):e0120827. 14. Van Walraven C, Bennett C, Jennings A, Austin PC, Forster AJ. Proportion of hospital readmissions deemed avoidable: a systematic review. Canadian Medical Association Journal.2011;183(7):E391-E402. 15. Saliba D, Kington R, Buchanan J, et al. Appropriateness of the decision to transfer nursing facility residents to the hospital. Journal of the American Geriatrics Society. 2000;48(2):154-163. 16. Boockvar K, LaCorte HC, Giambanco V, Fridman B, Siu A. Medication reconciliation for reducing drug-discrepancy adverse events. The American journal of geriatric pharmacotherapy. 2006;4(3):236-243. 17. Gregersen M, Zintchouk D, Borris LC, Damsgaard EM. A geriatric multidisciplinary and tailor-made hospital-at-home method in nursing home residents with hip fracture. Geriatric orthopaedic surgery 85 rehabilitation. 2011;2(4):148-154. 18. Crotty M, Rowett D, Spurling L, Giles LC, Phillips PA. Does the addition of a pharmacist transition coordinator improve evidence-based medication management and health outcomes in older adults moving from the hospital to a long-term care facility? Results of a randomized, controlled trial. The American journal of geriatric pharmacotherapy. 2004;2(4):257-264. 19. Jacobs B. Reducing heart failure hospital readmissions from skilled nursing facilities. Professional Case Management.2011;16(1):18-24. 20. Ward KT, Bates-Jensen B, Eslami MS, et al. Addressing delays in medication administration for patients transferred from the hospital to the nursing home: a pilot quality improvement project. The American journal of geriatric pharmacotherapy. 2008;6(4):205-211. 21. Zafirau WJ, Snyder SS, Hazelett SE, Bansal A, McMahon S. Improving transitions: efficacy of a transfer form to communicate patients' wishes. American Journal of Medical Quality. 2012;27(4):291-296. 22. Le Berre M, Maimon G, Sourial N, Guériton M, Vedel I. Impact of transitional care services for chronically Ill older patients: a systematic evidence review. Journal of the American Geriatrics Society. 2017;65(7):1597-1608. 23. AMDA - The Society for Post-Acute and Long-Term Care Medicine. About Post-Acute and Long-Term Care. 2015; https://paltc.org/content/about-post-acute-andlong-term-care. 24. Coleman EA, Boult C. Improving the quality of transitional care for persons with complex care needs. Journal of the American Geriatrics Society. 2003;51(4):556-557. 25. 
Hong QN, Fàbregues S, Bartlett G, et al. The Mixed Methods Appraisal Tool (MMAT) version 2018 for information professionals and researchers. Education for Information. 2018(Preprint):1-7. 26. Popay J, Roberts H, Sowden A, et al. Guidance on the conduct of narrative synthesis in systematic reviews. A product from the ESRC methods programme Version. 2006;1:b92. 27. Bergkvist A, Midlöv P, Höglund P, Larsson L, Bondesson Å, Eriksson T. Improved quality in the hospital discharge summary reduces medication errors-LIMM: Landskrona Integrated Medicines Management.European journal of clinical pharmacology. 2009;65(10):1037-1046. 28. Midlöv P, Bahrani L, Seyfali M, Höglund P, Rickhag E, Eriksson T. The effect of medication reconciliation in elderly patients at hospital discharge. International journal of clinical pharmacy.2012;34(1):113-119. 29. Harvey P, Storer M, Berlowitz DJ, Jackson B, Hutchinson A, Lim WK. Feasibility and impact of a post-discharge geriatric evaluation and management service for patients from residential care: the Residential Care Intervention Program in the Elderly (RECIPE). BMC geriatrics. 2014;14(1):48. 30. Catic AG, Berg AI, Moran JA, et al. Preliminary data from an advanced dementia consult service: integrating research, education, and clinical expertise. Journal of the American Geriatrics Society.2013;61(11):2008-2012. 31. Boockvar K, Fishman E, Kyriacou CK, Monias A, Gavi S, Cortes T. Adverse events due to discontinuations in drug use and dose changes in patients transferred between acute and long-term care facilities. Archives of internal medicine. 2004;164(5):545-550. 32. Desai R, Williams CE, Greene SB, Pierson S, Hansen RA. Medication errors during patient transitions into nursing homes: characteristics and association with patient harm. The American journal of geriatric pharmacotherapy. 2011;9(6):413-422. 33. Cwinn MA, Forster AJ, Cwinn AA, Hebert G, Calder L, Stiell IG. Prevalence of information gaps for seniors transferred from nursing homes to the emergency department. Canadian Journal of Emergency Medicine. 2009;11(5):462-472. 34. Kliff S. The fax of life: Why American medicine still runs on fax machines. Healthcare 2018; https://www.vox.com/health-care/2017/10/30/16228054/americanmedical-system-fax-machines-why. 35. McCloskey RM. Caring for patients with dementia in an acute care environment. Geriatric Nursing. 2004;25(3):139-144. 36. Helvik A-S, Engedal K, Benth JŠ, Selbæk G. Prevalence and severity of dementia in nursing home residents. Dementia and geriatric cognitive disorders. 2015;40(3-4):166-177. 37. Conway J, Higgins I, Hullick C, Hewitt J, Dilworth S. Nurse-led ED support for residential aged care facility staff: an evaluation study.International emergency nursing. 2015;23(2):190-196. 38. Daras LC, Wang JM, Ingber MJ, et al. What are nursing facilities doing to reduce potentially avoidable hospitalizations? Journal of the American Medical Directors Association. 2017;18(5):442-444. 39. Bayliss EA, Ellis JL, Shoup JA, Zeng C, McQuillan DB, Steiner JF. Effect of continuity of care on hospital utilization for seniors with multiple medical conditions in an integrated health care system. The Annals of Family Medicine. 2015;13(2):123-129.

\section{Funding}

This work was supported by funding from the Quebec Network for Research on Aging (RQRV).

\section{Acknowledgments}

We would like to acknowledge Geneviève Gore for her helpful guidance to define literature search strategies and Quan Nha Hong for her continuous support with the familiarization with the MMAT tool.

\section{Conflicts of interest}

The authors have no financial or personal conflicts to declare. 


\section{Table 1. Characteristics of the eleven included studies.}

\begin{tabular}{|c|c|c|c|c|c|}
\hline $\begin{array}{l}1^{\text {st }} \text { author } \\
\text { (year) / } \\
\text { Country }\end{array}$ & Study design & $\begin{array}{l}\text { Mean age (sd) } \\
\text { (intervention } \\
\text { /control) Female } \\
\% \text { (intervention } \\
/ \text { control) }\end{array}$ & $\begin{array}{l}\text { Total sample } \\
\text { size }\end{array}$ & $\begin{array}{l}\text { Intervention } \\
\text { Description } \\
\text { Coordination } \\
\text { measures with } \\
\text { LTCFs }\end{array}$ & $\begin{array}{l}\text { Healthcare } \\
\text { professionals } \\
\text { involved: } \\
\text { 1-nurse; } \\
\text { 2-physician; 3- } \\
\text { physiotherapist; } \\
\text { 4-pharmacist; } \\
\text { 5-other }\end{array}$ \\
\hline $\begin{array}{l}\text { Bergkvist (2009) } \\
\text { / Sweden }\end{array}$ & Pre-Post & $\begin{array}{l}84(6.2) / 84 \\
(6.7) 71.2 / 60.3\end{array}$ & 115 & $\begin{array}{l}\text { Medication } \\
\text { reconciliation } \\
\text { done at hospital } \\
\text { admission } \\
\text { (pharmacist), } \\
\text { creation of a } \\
\text { systematic } \\
\text { medication care } \\
\text { plan, updated } \\
\text { continuously } \\
\text { (care team), } \\
\text { patient } \\
\text { information and } \\
\text { education based } \\
\text { on specially } \\
\text { developed drug } \\
\text { information } \\
\text { leaflets } \\
\text { (pharmacist), } \\
\text { discharge } \\
\text { summary } \\
\text { (physician) } \\
\text { checked by the } \\
\text { pharmacist, } \\
\text { reconcilia- } \\
\text { tion } \backslash \text { adjustment } \\
\text { through } \\
\text { discussion with } \\
\text { the physician } \\
\text { before the } \\
\text { patient's } \\
\text { discharge. } \\
\text { Discharge } \\
\text { summary, } \\
\text { carefully checked } \\
\text { and approved by } \\
\text { both pharmacist } \\
\text { and physician }\end{array}$ & 2,4 \\
\hline
\end{tabular}




\begin{tabular}{|c|c|c|c|c|c|}
\hline $\begin{array}{l}1^{\text {st }} \text { author } \\
\text { (year) / } \\
\text { Country }\end{array}$ & Study design & $\begin{array}{l}\text { Mean age (sd) } \\
\text { (intervention } \\
\text { /control) Female } \\
\% \text { (intervention } \\
/ \text { control) }\end{array}$ & $\begin{array}{l}\text { Total sample } \\
\text { size }\end{array}$ & $\begin{array}{l}\text { Intervention } \\
\text { Description } \\
\text { Coordination } \\
\text { measures with } \\
\text { LTCFs }\end{array}$ & $\begin{array}{l}\text { Healthcare } \\
\text { professionals } \\
\text { involved: } \\
\text { 1-nurse; } \\
\text { 2-physician; 3- } \\
\text { physiotherapist; } \\
\text { 4-pharmacist; } \\
\text { 5-other }\end{array}$ \\
\hline $\begin{array}{l}\text { Boockvar (2006) } \\
\text { / United States }\end{array}$ & Pre-Post & $\begin{array}{l}84.4(8.8) / 83.9 \\
(10.3) 78.2 / \\
82.7\end{array}$ & 168 & $\begin{array}{l}\text { Medication } \\
\text { reconciliation on } \\
\text { patient discharge } \\
\text { (pharmacist) } \\
\text { charted on a } \\
\text { communication } \\
\text { form and sent to } \\
\text { the LTCF } \\
\text { physician. The } \\
\text { form becomes } \\
\text { part of the } \\
\text { LTCF pharmacy } \\
\text { record. } \\
\text { Communication } \\
\text { form sent to the } \\
\text { LTCF physician }\end{array}$ & 2,4 \\
\hline
\end{tabular}




\begin{tabular}{|c|c|c|c|c|c|}
\hline $\begin{array}{l}1^{\text {st }} \text { author } \\
\text { (year) / } \\
\text { Country }\end{array}$ & Study design & $\begin{array}{l}\text { Mean age (sd) } \\
\text { (intervention } \\
\text { /control) Female } \\
\% \text { (intervention } \\
/ \text { control) }\end{array}$ & $\begin{array}{l}\text { Total sample } \\
\text { size }\end{array}$ & $\begin{array}{l}\text { Intervention } \\
\text { Description } \\
\text { Coordination } \\
\text { measures with } \\
\text { LTCFs }\end{array}$ & $\begin{array}{l}\text { Healthcare } \\
\text { professionals } \\
\text { involved: } \\
\text { 1-nurse; } \\
\text { 2-physician; 3- } \\
\text { physiotherapist; } \\
\text { 4-pharmacist; } \\
\text { 5-other }\end{array}$ \\
\hline $\begin{array}{l}\text { Catic (2013) / } \\
\text { United States }\end{array}$ & $\begin{array}{l}\text { Pre-Post (pilot } \\
\text { study) }\end{array}$ & $\begin{array}{l}90 / 84.460 / \\
62.5\end{array}$ & 29 & $\begin{array}{l}\text { In- } \\
\text { person/telephone } \\
\text { meeting with the } \\
\text { proxy within } 24 h \\
\text { of admission. A } \\
\text { pocket-sized } \\
\text { printed booklet } \\
\text { for decision } \\
\text { support was } \\
\text { given to all } \\
\text { proxies to } \\
\text { provide } \\
\text { standardized } \\
\text { information. At } \\
\text { discharge, a } \\
\text { 1-page report } \\
\text { summarizing the } \\
\text { consultation } \\
\text { focusing on rec- } \\
\text { ommendations } \\
\text { for symptom } \\
\text { control, goals of } \\
\text { care, and } \\
\text { advance care } \\
\text { planning was } \\
\text { sent to the } \\
\text { patient's } \\
\text { primary care } \\
\text { providers. Two } \\
\text { weeks } \\
\text { post-discharge, } \\
\text { the proxy was } \\
\text { telephoned for } \\
\text { support and to } \\
\text { review the } \\
\text { patient's health } \\
\text { status, advance } \\
\text { care planning, } \\
\text { decision making, } \\
\text { and proxy needs. } \\
\text { pront to } \\
\text { pare }\end{array}$ & $\begin{array}{l}1 \text { (palliative care } \\
\text { nurse), } 2 \\
\text { (geriatrician) }\end{array}$ \\
\hline
\end{tabular}




\begin{tabular}{|c|c|c|c|c|c|}
\hline $\begin{array}{l}1^{\text {st }} \text { author } \\
\text { (year) / } \\
\text { Country }\end{array}$ & Study design & $\begin{array}{l}\text { Mean age (sd) } \\
\text { (intervention } \\
\text { /control) Female } \\
\% \text { (intervention } \\
\text { / control) }\end{array}$ & $\begin{array}{l}\text { Total sample } \\
\text { size }\end{array}$ & $\begin{array}{l}\text { Intervention } \\
\text { Description } \\
\text { Coordination } \\
\text { measures with } \\
\text { LTCFs }\end{array}$ & $\begin{array}{l}\text { Healthcare } \\
\text { professionals } \\
\text { involved: } \\
\text { 1-nurse; } \\
\text { 2-physician; 3- } \\
\text { physiotherapist; } \\
\text { 4-pharmacist; } \\
\text { 5-other }\end{array}$ \\
\hline $\begin{array}{l}\text { Crotty (2004) / } \\
\text { Australia }\end{array}$ & $\begin{array}{l}\text { Randomized } \\
\text { controlled trial }\end{array}$ & $\begin{array}{l}82 / 83.458 .9 / \\
63\end{array}$ & 110 & 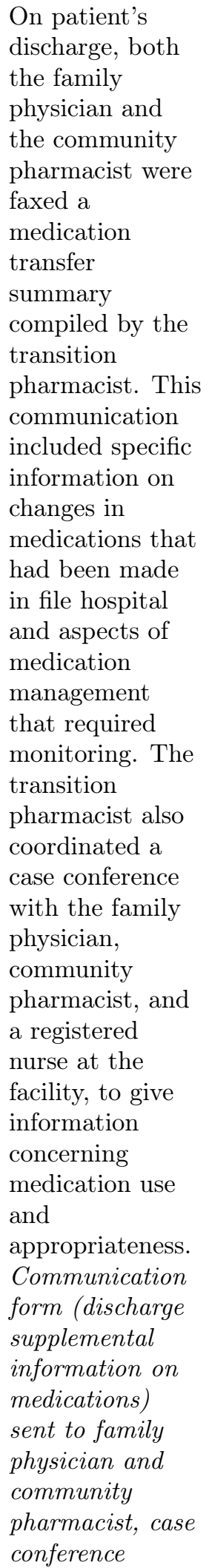 & 2,4 \\
\hline
\end{tabular}




\begin{tabular}{|c|c|c|c|c|c|}
\hline $\begin{array}{l}1^{\text {st }} \text { author } \\
\text { (year) / } \\
\text { Country }\end{array}$ & Study design & $\begin{array}{l}\text { Mean age (sd) } \\
\text { (intervention } \\
\text { /control) Female } \\
\% \text { (intervention } \\
/ \text { control) }\end{array}$ & $\begin{array}{l}\text { Total sample } \\
\text { size }\end{array}$ & $\begin{array}{l}\text { Intervention } \\
\text { Description } \\
\text { Coordination } \\
\text { measures with } \\
\text { LTCFs }\end{array}$ & $\begin{array}{l}\text { Healthcare } \\
\text { professionals } \\
\text { involved: } \\
\text { 1-nurse; } \\
\text { 2-physician; 3- } \\
\text { physiotherapist; } \\
\text { 4-pharmacist; } \\
\text { 5-other }\end{array}$ \\
\hline $\begin{array}{l}\text { Elliott (2012) / } \\
\text { Australia }\end{array}$ & Pre-Post & $\begin{array}{l}84 \text { (median) / } 84 \\
(\text { median) 62.8 } \\
58.9\end{array}$ & 428 & $\begin{array}{l}\text { A 7-day } \\
\text { residential care } \\
\text { medication } \\
\text { administration } \\
\text { chart (IRCMAC) } \\
\text { was prepared } \\
\text { (hospital } \\
\text { pharmacist). } \\
\text { The IRCMAC, } \\
\text { photocopy of the } \\
\text { discharge } \\
\text { prescriptions and } \\
\text { instructions for } \\
\text { using the } \\
\text { IRCMAC were } \\
\text { was placed with } \\
\text { the discharge } \\
\text { medications and } \\
\text { transported with } \\
\text { the patient. The } \\
\text { pharmacist } \\
\text { telephoned the } \\
\text { RCF prior to } \\
\text { discharge to } \\
\text { notify them that } \\
\text { an IRCMAC } \\
\text { would be } \\
\text { provided. } \\
\text { Communication } \\
\text { form (IRCMAC) } \\
\text { sent to the } \\
\text { LTCF, phone } \\
\text { call prior } \\
\text { discharge to } \\
\text { notify }\end{array}$ & 4 \\
\hline
\end{tabular}




\begin{tabular}{|c|c|c|c|c|c|}
\hline $\begin{array}{l}\mathbf{1}^{\text {st }} \text { author } \\
\text { (year) / } \\
\text { Country }\end{array}$ & Study design & $\begin{array}{l}\text { Mean age (sd) } \\
\text { (intervention } \\
\text { /control) Female } \\
\% \text { (intervention } \\
\text { / control) }\end{array}$ & $\begin{array}{l}\text { Total sample } \\
\text { size }\end{array}$ & $\begin{array}{l}\text { Intervention } \\
\text { Description } \\
\text { Coordination } \\
\text { measures with } \\
\text { LTCFs }\end{array}$ & $\begin{array}{l}\text { Healthcare } \\
\text { professionals } \\
\text { involved: } \\
\text { 1-nurse; } \\
\text { 2-physician; 3- } \\
\text { physiotherapist; } \\
\text { 4-pharmacist; } \\
\text { 5-other }\end{array}$ \\
\hline $\begin{array}{l}\text { Gregersen (2011) } \\
\text { / Denmark }\end{array}$ & $\begin{array}{l}\text { Non-randomized } \\
\text { trial }\end{array}$ & $\begin{array}{l}88(2 \\
\text { intervention } \\
\text { groups } \\
\text { combined }) \\
\text { tailored group }= \\
83 \% / \\
\text { standardized } \\
\text { group }=68 \%\end{array}$ & 238 & $\begin{array}{l}\text { Early discharge } \\
\text { planning and } \\
\text { in-hospital } \\
\text { assessments, } 2 \\
\text { post-discharge } \\
\text { follow-up visits } \\
\text { (or more in the } \\
\text { tailored group), } \\
\text { discharge } \\
\text { summary sent to } \\
\text { GP. Discharge } \\
\text { summary sent to } \\
\text { GP }\end{array}$ & $1,2,3$ \\
\hline $\begin{array}{l}\text { Harvey (2014) / } \\
\text { Australia }\end{array}$ & $\begin{array}{l}\text { Randomized } \\
\text { controlled trial }\end{array}$ & $\begin{array}{l}83.8(7) / 86.7 \\
(7) 66.7 / 59.3\end{array}$ & 116 & $\begin{array}{l}\text { Tailored care } \\
\text { plan } \\
\text { development and } \\
\text { in-hospital } \\
\text { assessments, } \\
\text { with possibility } \\
\text { of additional } \\
\text { visits as } \\
\text { required, } \\
\text { education and } \\
\text { support to the } \\
\text { LTCF staff and } \\
\text { the GP. } \\
\text { "E]ducation and } \\
\text { support" of the } \\
\text { GP }\end{array}$ & $\begin{array}{l}1 \text { (aged care } \\
\text { nurse), } 2 \\
\text { (geriatrician) }\end{array}$ \\
\hline
\end{tabular}




\begin{tabular}{|c|c|c|c|c|c|}
\hline $\begin{array}{l}1^{\text {st }} \text { author } \\
\text { (year) / } \\
\text { Country }\end{array}$ & Study design & $\begin{array}{l}\text { Mean age }(\mathbf{s d}) \\
\text { (intervention } \\
\text { /control) Female } \\
\% \text { (intervention } \\
/ \text { control) }\end{array}$ & $\begin{array}{l}\text { Total sample } \\
\text { size }\end{array}$ & $\begin{array}{l}\text { Intervention } \\
\text { Description } \\
\text { Coordination } \\
\text { measures with } \\
\text { LTCFs }\end{array}$ & $\begin{array}{l}\text { Healthcare } \\
\text { professionals } \\
\text { involved: } \\
\text { 1-nurse; } \\
\text { 2-physician; 3- } \\
\text { physiotherapist; } \\
\text { 4-pharmacist; } \\
\text { 5-other }\end{array}$ \\
\hline $\begin{array}{l}\text { Jacobs (2011) / } \\
\text { United States }\end{array}$ & $\begin{array}{l}\text { Pre-Post (quality } \\
\text { improvement } \\
\text { initiative) }\end{array}$ & $\begin{array}{l}\text { not reported/ no } \\
\text { control group } \\
\text { not reported / no } \\
\text { control group }\end{array}$ & not reported & $\begin{array}{l}\text { Letter sent to } \\
\text { the LTCF with } \\
\text { contact } \\
\text { information, } \\
\text { phone contact } \\
\text { with the LTCF } \\
\text { facility within } 2 \\
\text { days of discharge } \\
\text { and review of the } \\
\text { discharge orders, } \\
\text { confirmation } \\
\text { that the patient } \\
\text { will see a doctor } \\
\text { within } 5 \text { days. } \\
\text { Letter sent to the } \\
\text { LTCF, phone } \\
\text { call }\end{array}$ & $\begin{array}{l}1 \text { (heart failure } \\
\text { nurse, RN care } \\
\text { coordinator) }\end{array}$ \\
\hline
\end{tabular}




\begin{tabular}{|c|c|c|c|c|c|}
\hline $\begin{array}{l}1^{\text {st }} \text { author } \\
\text { (year) / } \\
\text { Country }\end{array}$ & Study design & $\begin{array}{l}\text { Mean age (sd) } \\
\text { (intervention } \\
\text { /control) Female } \\
\% \text { (intervention } \\
\text { / control) }\end{array}$ & $\begin{array}{l}\text { Total sample } \\
\text { size }\end{array}$ & $\begin{array}{l}\text { Intervention } \\
\text { Description } \\
\text { Coordination } \\
\text { measures with } \\
\text { LTCFs }\end{array}$ & $\begin{array}{l}\text { Healthcare } \\
\text { professionals } \\
\text { involved: } \\
\text { 1-nurse; } \\
\text { 2-physician; 3- } \\
\text { physiotherapist; } \\
\text { 4-pharmacist; } \\
\text { 5-other }\end{array}$ \\
\hline $\begin{array}{l}\text { Midlov (2012) / } \\
\text { Sweden }\end{array}$ & Pre-Post & $\begin{array}{l}\text { period1: } 84.4 \\
\text { (65-99)/ period2: } \\
85.6(69-102) / \\
\text { period 3: } 85.1 \\
(66-95) / \text { no } \\
\text { control group } \\
\text { period1: } 74 \% / \\
\text { period2: } 81 \% / \\
\text { period3: 68\% / } \\
\text { no control group }\end{array}$ & 123 & $\begin{array}{l}\text { Patient } \\
\text { education and } \\
\text { LIMM discharge } \\
\text { information } \\
\text { form. } \\
\text { Medication } \\
\text { reconciliation } \\
\text { upon admission } \\
\text { of the patient } \\
\text { (clinical } \\
\text { pharmacist) and } \\
\text { review and } \\
\text { monitoring of } \\
\text { medication } \\
\text { during hospital } \\
\text { stay according to } \\
\text { the } \\
\text { LIMM-model. } \\
\text { LIMM quality } \\
\text { control forms for } \\
\text { discharge } \\
\text { medication } \\
\text { reconciliation, } \\
\text { performed by } \\
\text { pharmacist who } \\
\text { gives suggestions } \\
\text { for } \\
\text { changes/corrections } \\
\text { to the physician } \\
\text { before patient } \\
\text { discharge } \\
\text { Medication list, } \\
\text { general } \\
\text { information and } \\
\text { report written } \\
\text { by the physician, } \\
\text { discussed at } \\
\text { discharge and } \\
\text { sent to the GP } \\
\text { sischarge forme GP } \\
\text { pent the }\end{array}$ & 2,4 \\
\hline
\end{tabular}




\begin{tabular}{|c|c|c|c|c|c|}
\hline $\begin{array}{l}1^{\text {st }} \text { author } \\
\text { (year) / } \\
\text { Country }\end{array}$ & Study design & $\begin{array}{l}\text { Mean age (sd) } \\
\text { (intervention } \\
\text { /control) Female } \\
\% \text { (intervention } \\
\text { / control) }\end{array}$ & $\begin{array}{l}\text { Total sample } \\
\text { size }\end{array}$ & $\begin{array}{l}\text { Intervention } \\
\text { Description } \\
\text { Coordination } \\
\text { measures with } \\
\text { LTCFs }\end{array}$ & $\begin{array}{l}\text { Healthcare } \\
\text { professionals } \\
\text { involved: } \\
\text { 1-nurse; } \\
\text { 2-physician; 3- } \\
\text { physiotherapist; } \\
\text { 4-pharmacist; } \\
\text { 5-other }\end{array}$ \\
\hline $\begin{array}{l}\text { Ward (2008) / } \\
\text { United States }\end{array}$ & $\begin{array}{l}\text { Non-randomized } \\
\text { trial (quality } \\
\text { improvement } \\
\text { initiative) }\end{array}$ & $\begin{array}{l}85.6(\text { no sd) } / \\
78.6(\text { no sd) } \\
\text { Cumulative } \\
\text { mean age (both } \\
\text { groups) }=83.0 \\
(9.22) 50 / 60\end{array}$ & 20 & $\begin{array}{l}\text { LTCF specific } \\
\text { communication } \\
\text { form for } \\
\text { discharge } \\
\text { instructions and } \\
\text { medication list, } \\
\text { transmitted } \\
\text { before discharge } \\
\text { instead of with } \\
\text { the patient - } \\
\text { allowing contact } \\
\text { with pharmacist } \\
\text { before discharge } \\
\text { LTCF specific } \\
\text { communication } \\
\text { form (so that } \\
\text { nurses won't } \\
\text { have to enter it } \\
\text { in the charts, } \\
\text { already in the } \\
\text { right format), } \\
\text { transmitted } \\
\text { before discharge } \\
\text { instead of with } \\
\text { the patient (so } \\
\text { that the staff has } \\
\text { the time to order } \\
\text { medication } \\
\text { before the } \\
\text { patient's arrival) }\end{array}$ & 1,2 \\
\hline $\begin{array}{l}\text { Zafirau (2012) / } \\
\text { United States }\end{array}$ & $\begin{array}{l}\text { Pre-Post (quality } \\
\text { improvement } \\
\text { initiative) }\end{array}$ & $\begin{array}{l}76 / 72.853 .9 / \\
50\end{array}$ & 247 & $\begin{array}{l}\text { New } \\
\text { standardized } \\
\text { transfer form } \\
\text { and education } \\
\text { about its use. } \\
\text { Standardized } \\
\text { transfer form } \\
\text { used between the } \\
\text { acute care and } \\
\text { the LTCF }\end{array}$ & $\begin{array}{l}\text { 1, } 5 \text { (LTCF staff, } \\
\text { director of } \\
\text { nursing) }\end{array}$ \\
\hline
\end{tabular}




\section{Table 2. Effects of transitional care interventions on quality of care indicators}

\begin{tabular}{|c|c|c|c|}
\hline Reference & Follow-up time & & $P$ value \\
\hline MEDICATION & MEDICATION & MEDICATION & MEDICATION \\
\hline PROBLEMS & PROBLEMS & PROBLEMS & PROBLEMS \\
\hline \multirow[t]{4}{*}{ Bergkvist et al, 2009} & At discharge & $\begin{array}{l}\text { Patients with [?] } 1 \\
\text { medication error }(\mathrm{n} / \mathrm{N} \text {, } \\
\%): \\
\text { Intervention }=14 / 52 \\
(27 \%) \text {; Control }=23 / 63 \\
(37 \%)\end{array}$ & $\mathrm{NR}^{\mathrm{a}}$ \\
\hline & & $\begin{array}{l}\text { Patients with [?] } 3 \\
\text { medication errors } \\
(\mathrm{n} / \mathrm{N}, \%): \\
\text { Intervention }=3 / 52 \\
(6 \%) ; \text { Control }=11 / 63 \\
(17 \%)\end{array}$ & NR \\
\hline & & $\begin{array}{l}\text { Patients with [?] } 5 \\
\text { medication errors } \\
(\mathrm{n} / \mathrm{N}, \%): \\
\text { Intervention }=1 / 52 \\
(2 \%) ; \text { Control }=5 / 63 \\
(8 \%)\end{array}$ & NR \\
\hline & & $\begin{array}{l}\text { Medications with } \\
\text { medications errors } \\
(\mathrm{n} / \mathrm{N}, \%): \\
\text { Intervention }=25 / 520 \\
(5 \%) ; \text { Control }=66 / 549 \\
(12 \%)\end{array}$ & NR \\
\hline \multirow[t]{2}{*}{ Boockvar et al, 2006} & At discharge & $\begin{array}{l}\text { Drug Discrepancy Risk } \\
\text { Index (mean, sd, N): } \\
\text { Post =11.3 (5.9), } \\
\mathrm{N}=87 ; \text { Pre=9.1 (5.1), } \\
\mathrm{N}=81\end{array}$ & $\mathrm{p}=0.004$ \\
\hline & & $\begin{array}{l}\text { Discrepancy-Related } \\
\text { Adverse Drug Events } \\
(\mathrm{n}, \%): \text { Post }=1(2.3 \%) ; \\
\text { Pre=10 }(14.5 \%)\end{array}$ & NR \\
\hline Crotty et al, 2004 & At discharge & $\begin{array}{l}\text { Discrepancy between } \\
\text { medication summary } \\
\text { and medication sent } \\
(\mathrm{n} / \mathrm{N}, \%) \text { : } \\
\text { Intervention }=32 / 56 \\
(57 \%) ; \text { Control }=26 / 54 \\
(48 \%)\end{array}$ & $\mathrm{p}=0.259$ \\
\hline
\end{tabular}




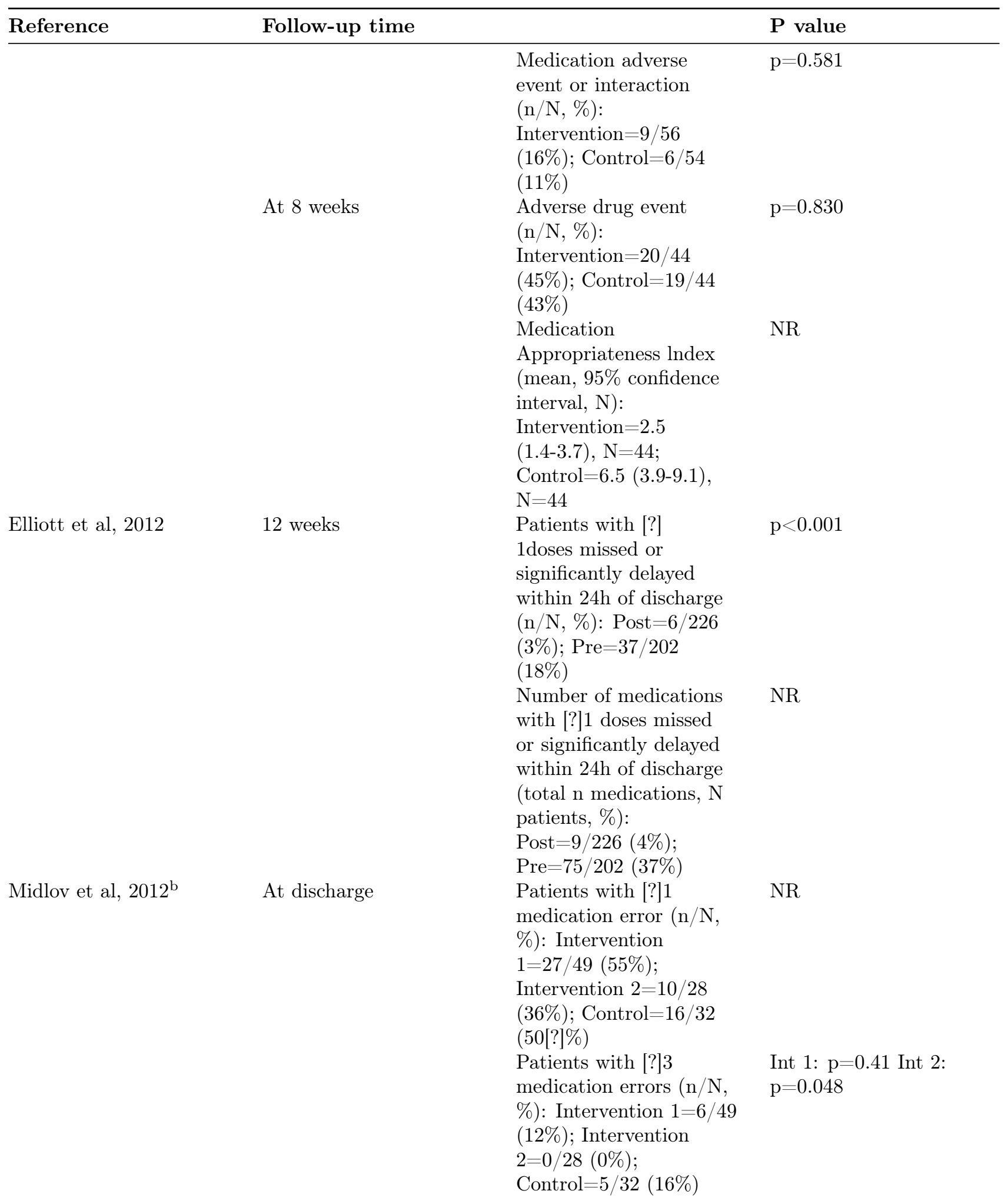




\begin{tabular}{|c|c|c|c|}
\hline Reference & Follow-up time & & $\mathbf{P}$ value \\
\hline Ward et al, 2008 & At discharge & 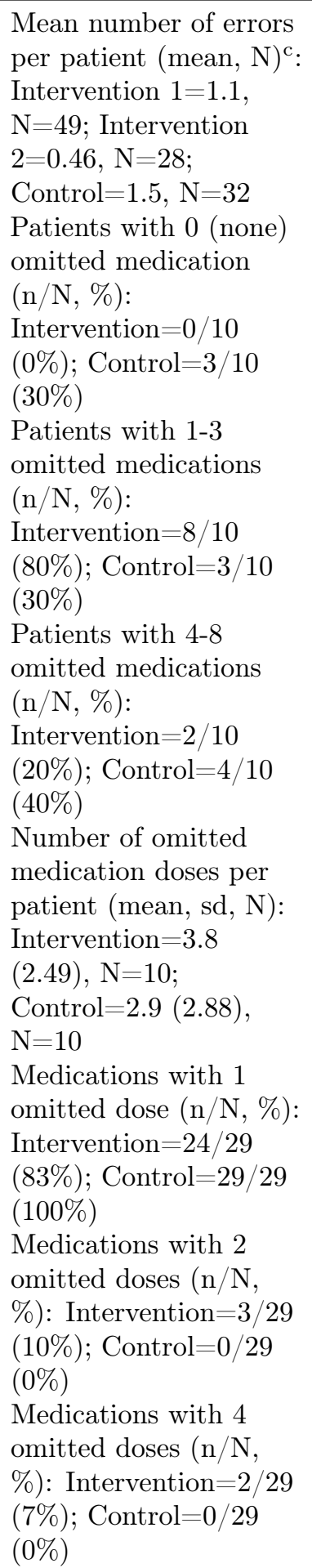 & $\begin{array}{l}\mathrm{NR} \\
\mathrm{p}>0.05^{\mathrm{d}}\end{array}$ \\
\hline
\end{tabular}




\begin{tabular}{|c|c|c|c|}
\hline Reference & Follow-up time & & $\mathbf{P}$ value \\
\hline & & $\begin{array}{l}\text { Doses of omitted } \\
\text { medications with } \\
\text { potential low negative } \\
\text { consequences }(\mathrm{n} / \mathrm{N}, \%) \text { : } \\
\text { Intervention }=5 / 38 \\
(13 \%) \text {; Control=12/29 } \\
(41 \%) \\
\text { Doses of omitted } \\
\text { medications with } \\
\text { potential medium } \\
\text { negative consequences } \\
\text { (n/N, \%): } \\
\text { Intervention=18/38 } \\
(47 \%) ; \text { Control=10/29 } \\
(34 \%) \\
\text { Doses of omitted } \\
\text { medications with } \\
\text { potential high negative } \\
\text { consequences }(\mathrm{n} / \mathrm{N}, \%) \text { : } \\
\text { Intervention=15/38 } \\
(39 \%) ; \text { Control=7/29 } \\
(24 \%)\end{array}$ & $\mathrm{p}>0.05^{\mathrm{d}}$ \\
\hline ADVANCE & ADVANCE & ADVANCE & ADVANCE \\
\hline DIRECTIVES & DIRECTIVES & DIRECTIVES & DIRECTIVES \\
\hline \multirow[t]{3}{*}{ Harvey et al, 2014} & At 6 months & $\begin{array}{l}\text { Caregiver/patient } \\
\text { satisfied with the } \\
\text { Advanced Care } \\
\text { Planning }(\mathrm{n} / \mathrm{N}, \%): \\
\text { Intervention }=17 / 20 \\
(85 \%) ; \text { Control }=9 / 24 \\
(38 \%)\end{array}$ & $\mathrm{p}=0.002$ \\
\hline & & $\begin{array}{l}\text { Participation in at } \\
\text { least } 1 \text { family meeting } \\
\text { and Advanced Care } \\
\text { Planning discussion } \\
(\mathrm{n} / \mathrm{N}, \%) \text { : } \\
\text { Intervention }=36 / 54 \\
(67 \%) ; \text { Control=Not } \\
\text { assessed }\end{array}$ & $\mathrm{N} / \mathrm{A}^{\mathrm{e}}$ \\
\hline & & $\begin{array}{l}\text { Documentation of } \\
\text { advanced directives } \\
(\mathrm{n} / \mathrm{N}, \%): \\
\text { Intervention }=36 / 54 \\
(67 \%) ; \text { Control=Not } \\
\text { assessed }\end{array}$ & $\mathrm{N} / \mathrm{A}^{\mathrm{e}}$ \\
\hline
\end{tabular}




\begin{tabular}{|c|c|c|c|}
\hline Reference & Follow-up time & & $\mathbf{P}$ value \\
\hline Zafirau et al, 2012 & At 30 days & $\begin{array}{l}\text { Advance directives } \\
\text { status discordance } \\
\text { between hospital and } \\
\text { LTCF }(\%, \mathrm{~N}) \text { : } \\
\text { Post }=16.3 \%, \mathrm{~N}=117 ; \\
\text { Pre }=26.7 \%, \mathrm{~N}=130 \\
\text { Do-Not-Resuscitate } \\
\text { orders discordance } \\
\text { between hospital and } \\
\text { LTCF }(\%, \mathrm{~N}): \\
\text { Post }=27.1 \%, \mathrm{~N}=117 ; \\
\text { Pre }=40 \%, \mathrm{~N}=130\end{array}$ & $\mathrm{p}=0.038$ \\
\hline
\end{tabular}

a Not reported

b Intervention 1 (period 2)=medication list in the hospital electronic patient medical record and quality control of discharge medication reconciliation; Intervention 2 (period 3)=same as intervention 1, with an additional focus on specific medication dispensing system

${ }^{\mathrm{c}}$ No standard deviation (sd) reported

d The authors used $\chi^{2}$ tests for categorical variables, giving $\mathrm{p}$ values only for the difference in the outcomes overall distribution by group (Patients with omitted medications: 0 medication, 1-3 medications, 4-8 medications; Omitted doses of different medications: 1, 2, 4; Doses of omitted medications by potential for negative consequences: high, medium, low)

e Not applicable

\section{Table 3. Effects of transitional care interventions on Clinical Out- comes and Satisfaction}

\begin{tabular}{lll}
\hline Reference & Follow-up time & \\
\hline MORTALITY & MORTALITY & MORTALIT \\
Boockvar et al, 2006 $_{\text {Gregersen et al, 2011c }}$ & 2 months & Death or readn \\
& 30 days & Number of dea \\
Harvey et al, 2014 & 90 days & Number of dea \\
MOBILITY, FUNCTION AND PAIN & 6 months & Number of dea \\
Crotty et al, 2004 & MOBILITY, FUNCTION AND PAIN & MOBILITY, \\
& 8 weeks & Number of par \\
Gregersen et al, 2011 & & Number of par \\
CONFUSION/BEHAVIORAL SYMPTOMS & CONFUSION/BEHAVIORAL SYMPTOMS & Number of par \\
Crotty et al, 2004 & 8 weeks & Number of par \\
& & Number of par \\
SATISFACTION INDICATORS & SATISFACTION INDICATORS & SATISFACT \\
Catic et al, 2013 & 30 days & Caregivers scor \\
Elliott et al, 2012 & 12 weeks & Physicians repd \\
\end{tabular}


Reference

Harvey et al, 2014
Follow-up time

6 months
Physicians repc Physicians agre Caregiver/patic

${ }^{a}$ Mixed data on mortality and readmission, no data on mortality only were reported. Overall data only, no specific numbers per groups were reported

b Not applicable

${ }^{\mathrm{c}}$ Intervention $1=$ Standardized home-based rehabilitation; Intervention 2=Tailor-made hospital-at-home intervention; no control group

${ }^{\mathrm{d}} \mathrm{NR}=$ Not reported

\section{Table 4. Effects of transitional care interventions on healthcare services use}

\begin{tabular}{ll}
\hline Reference & Follow-u \\
\hline HOSPITAL READMISSION & HOSPIT \\
Boockvar et al, 2006 & 2 months \\
Crotty et al, 2004 & 8 weeks \\
Gregersen et al, 2011 d & 90 days \\
Harvey et al, 2014 & 6 months
\end{tabular}

Jacobs et al, 2011

Zafirau et al, 2012

6 months

30 days

EMERGENCY DEPARTMENT VISITS

Harvey et al, 2014

HOSPITAL DAYS

Boockvar et al, 2006

Gregersen et al, 2011 ${ }^{\mathrm{d}}$

Harvey et al, 2014

Midlov et al, $2012^{\mathrm{f}}$

Zafirau et al, 2012
EMERGENCY DEPARTMENT VISITS

6 months

HOSPITAL DAYS

2 months

90 days

6 months
Follow-up time

HOSPITAL READM

Death or readmission $(\%$

Hospital usage ${ }^{c}(\mathrm{n} / \mathrm{N}$, ?

Number of participants

Number of participants

Total number of acute $c$

Mean number of acute c

Total number of subacu

Mean number of subacu

Total number of readmi

Mean number of readmi

Number of participants

Number of participants

EMERGENCY DEP

Total number of Emerge

HOSPITAL DAYS

Index/Subsequent readn Index length of stay in c Total number of index $b$ Mean number of index $b$ Total number of acute $\mathrm{c}$ Mean number of acute $c$ Index length of stay in c Index length of stay in c

${ }^{a}$ Mortality and readmission as a composite outcome was reported.

b Not applicable

${ }^{c}$ Hospital readmissions and Emergency Department as a composite outcome was reported. 
${ }^{\mathrm{d}}$ Intervention $1=$ Standardized home-based rehabilitation; Intervention 2=Tailor-made hospital-at-home intervention; no control group

e Not reported

${ }^{\mathrm{f}}$ Intervention 1 (period 2)= electronic patient medication lists in medical record and quality control of discharge medication reconciliation;

Intervention 2 (period 3$)=$ same as intervention 1 , with an additional focus on a specific medication dispensing system.

\section{Figures captions}

Figure1. Flowchart of included studies.
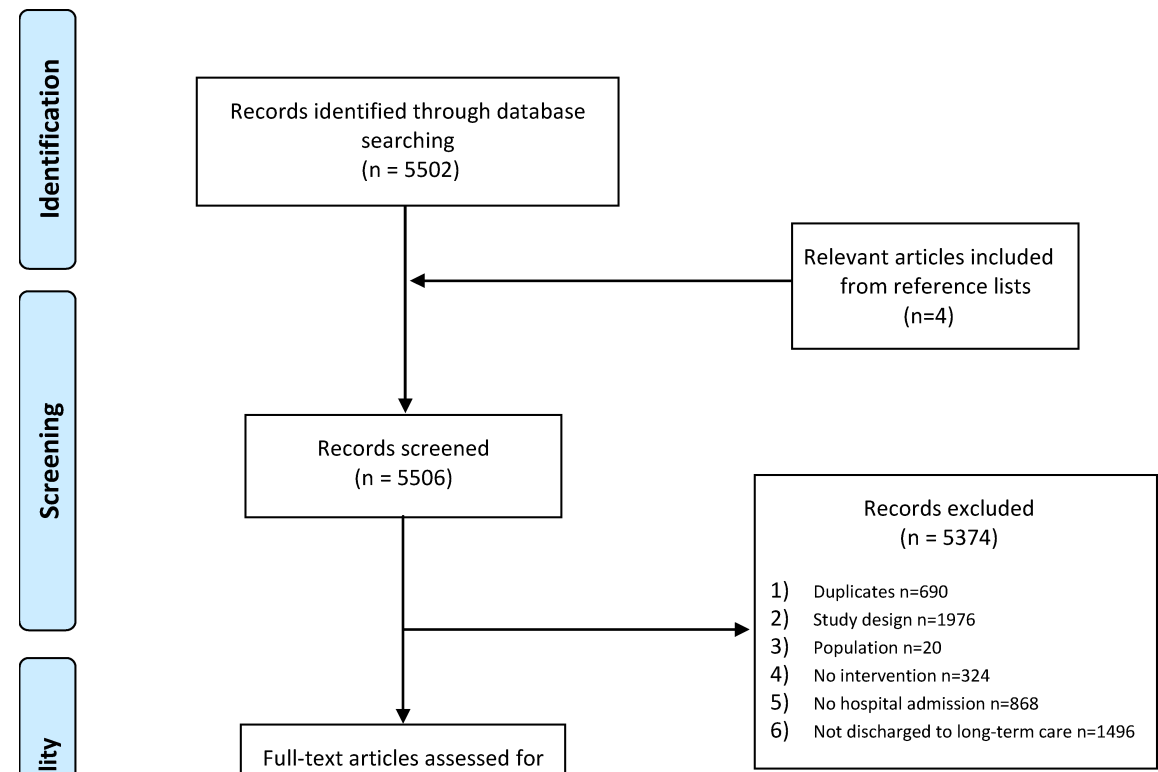

Full-text articles assessed for

eligibility

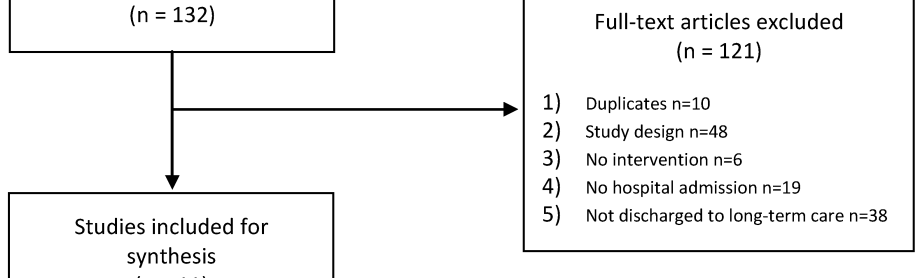

웜

synthesis

$(n=11)$ 